\title{
THE SCRUMPLED GEOGRAPHY OF LITERACIES FOR LEARNING
}

Richard Edwards

The Stirling Institute of Education

University of Stirling

Roz Ivanič

Literacy Research Centre

Lancaster University

Greg Mannion

The Stirling Institute of Education

University of Stirling

Correspondence to:

Richard Edwards

The Stirling Institute of Education

University of Stirling

Stirling FK9 4LA

Britain

e-mail: r.g.edwards@stir.ac.uk 


\section{THE SCRUMPLED GEOGRAPHY OF LITERACIES FOR LEARNING}

Abstract

This paper draws upon the experience of the Literacies for Learning in Further Education research project in the UK. The project explored the literacy demands of a number of curriculum areas and the literacy practices of students in their everyday lives, in order to identify those 'border literacies' which may act as resources for learning and attainment within their college courses. Drawing on Literacy Studies and aspects of actor-network theory, this article outlinesthe conceptual innovations that we found necessary arising from our data analysis, extending existing work on situating practice and boundary crossing to posit a conceptual landscape that we term the scrumpled geography of literacies for learning. This landscape is one in which purification, naturalization and translation are key concepts, where literacy practices are enacted as network effects of a folding of a range of micropractices into conglomerations.

Keywords: literacies, learning, literacy practices, actor-network theory, translation, purification, folding, border crossing 


\section{THE SCRUMPLED GEOGRAPHY OF LITERACIES FOR LEARNING}

\section{Introduction}

Literacy is identified as a key to student attainment and progression in numerous policy contexts. Limitations of reading and writing are held to place restrictions on individual, social and economic development. Anecdotally, teachers and lecturers complain endlessly that students do not read and cannot write. However, it is widely recognized also (e.g. Barton and Hamilton 1998) that many people identified as having literacy issues in educational contexts nonetheless negotiate many different forms of text in their everyday lives. The pedagogical challenge becomes therefore how to enable people to draw on their everyday capacities within educational domains. This was the challenge for the three year research project reported in this paper. However, in the process of conducting the project, we also came to question some of the existing conceptualizations of literacy in different domains. It is those theoretical explorations which are the focus of this particular article.

The paper then is theoretically driven and seeks to extend debates about how we can provide an adequate language of description for literacy and learning and their relationship in and across the varying domains of life. Drawing upon a study of literacy for learning in UK colleges (www.lancs.ac.uk/lflfe), we argue that the literacy demands and practices of education could benefit from being fashioned more around the practices people bring to student life from other domains of their lives than they are at present. Indeed, in many situations, such practices are often deliberately excluded as being precisely concerned with the everyday, the popular and therefore the 'less worthwhile'. In particular, drawing on aspects of actor-network theory (ANT), we employ the concepts of naturalizing, purification and translation to enable us to explore the different mobilizations and stabilizations of 
literacy. ANT has not been widely drawn upon in the study of education (Nespor 1994). It developed in the study of science and technology, but has spread more widely and is drawn upon to study how social practices become ordered and changed (Latour 1993, 2005, Czarniawska and Hernes 2005). ANT has become a diverse set of conceptual tools, only some of which are drawn upon here to explore how, as an effect of educational work, certain practices become stabilized as literacy from the multiplicity of communication that takes place across the social order. We refer to this, borrowing from Doel (1996), as the 'scrumpled geography' of literacies for learning. Scrumpling enacts both possibilities and constraints and points to the messiness of practice. These are unfamiliar concepts through which to explore educational practices but we believe them to offer different and generative possibilities for educational understanding.

The empirical context from which this conceptual landscape emerged is a recent study of literacy for learning (Ivanič et al. 2007, 2009). In this article therefore, we first provide an overview of the Literacies for Learning in Further Education research project on which this discussion draws, of the social view of literacy and of the conceptual resources that inform much existing work on literacy and learning. We then elaborate on how our data analysis gave rise to new conceptual insights. While our discussion is based upon the context of colleges in the UK, we believe the theoretical significance of the issues we are addressing is of much wider interest as it brings into relief some of the core structuring metaphors of educational discourse, in particular around notions of context, transfer and standards.

The Literacies for Learning in Further Education research project: Aims and assumptions 
The Literacies for Learning in Further Education (hereafter, LfLFE) research project was funded for three years from January 2004 as part of the United Kingdom's Teaching and Learning Research Programme (TLRP), administered by the Economic and Social Research Council (ESRC). The project involved collaboration between two universities and four further education (F.E.) colleges in England and Scotland. A central concern for the project was to understand how the literacy practices required of college life and being a student relate to the wide range of students' literacy practices in their everyday lives - the knowledge and capabilities they involve and the texts and modalities they address. We explored different ways of mobilizing students' everyday literacy practices to enhance their learning on 32 courses in thirteen curriculum areas. The intention was to achieve a critical understanding of the movements and flows of literacy practices in people's lives: how literacy practices are ordered and re-ordered, mobilized across domains (home-college, virtual-real, readingwriting), and what artifacts might mediate such mobilizations.

In the LfLFE project, literacy practices were initially viewed primarily as 'resources' for learning across the curriculum (Lee 1996). Although at the same time learning across the curriculum can provide purposeful contexts for literacy learning, this was not our focus. Our focus was on the other direction in the equation: the reading and writing which are entailed in learning on college courses, that is, what have been termed by some (e.g. Wyatt-Smith and Cumming 2003) 'curriculum literacies'. We were researching the literacy practices in which students participate in order to be successful in learning the content (however broadly conceived that content may be in terms of knowledge, understanding and capabilities) of their vocational, academic or leisure courses, and, where necessary, in demonstrating that learning in order to gain qualifications through assessment tasks. Inevitably, this brought into focus questions of what counts as literacy and the differential values placed upon different literacy 
practices. In other words, it raised questions of difference and its affirmations and denials in assembling the educated subject, and how best to conceptualize this.

\section{Orienting theory: Literacy as a social practice}

Traditionally, literacy has been taken to mean reading and writing formal paper-based texts using predetermined rules surrounding the use of a national language. This view sees literacy as an autonomous value-free attribute lying within the individual - a set of singular and transferable cognitive technical skills which can be taught, measured and tested at a level of competence against pre-specified standards. This is situated within a view of learning as acquisition. A range of initiatives are aimed at enhancing the attainment of literacy in this sense as part of the agenda for the improvement of 'basic skills', 'key skills', 'core skills', 'core competencies', 'essential skills' or 'learning to learn'. Such initiatives focus on the induction of people of all ages into at least 'functional' literacy and numeracy, and on the development of communication skills, computer literacy, and literacy-dependent so-called 'transferable skills'.

The LfLFE project sought to complement and inform practice and policies in relation to such initiatives. Many policies are located in the discourse of literacy as a set of autonomous linguistic skills and competencies (see Ivanič 2004a). This discourse is based on a certain view of literacy and leads to an idea that it can be taught, learned and demonstrated in educational institutions and this is transferable to other domains of life. Attempts to measure 'how much' literacy each individual has becomes a driver for the 'success' or 'failure' of the education system and individual teachers. Standards are enacted for what is taken to be literacy by excluding other forms of reading and writing and by specifying who is to be included within that particular regime of truth. This usually entails the privileging - in word if 
not always in deed - of extended forms of reading and writing. We will suggest later that such setting of standards for literacy and the measurement of individuals against them are part of the purification practices of education, which precisely rely on the separation and hierarchal privileging of certain domains over others.

The Literacy Studies approach, which was the starting point for the LfLFE project, offers a socially situated and socially constructed view of literacies as multiple, emergent and situated in particular social contexts (Barton 2007, Barton et al. 2000). This meshes with the tradition of locating learning within socio-cultural practices of participation that has become increasingly influential in educational research (e.g. Lave and Wenger 1991). It is an approach that encourages us to talk differently about how texts get read and written as embedded in the everyday and often mundane purposes and activities of life, including education. In this view, literacy practices are situated within the diverse domains of their use, and the practices within education, however privileged, are only further examples of 'situated literacies'.

While certain educational literacy practices are taken to be signs of an educated person, their relatedness to everyday practices can be somewhat limited. They remain situated within the domain of education, but this domain is precisely one which privileges abstracted and decontextualized forms of knowledge and communication (Lave 1996). The critique of abstracted literacy practices in education is a popular one among some literacy researchers. In his study of post-compulsory education, Kress (2001) found that there was no sense of connection either for teachers or students between the subject areas and there was a general lack of engagement by students. He criticizes schooling for enforcing insularity between 
subjects, with a loss of the potential to identify literacy practices which might support learning across the curriculum, and to value what students might value.

Recent work has further extended the notion of literacy, emphasizing how social, economic and technological factors mean that texts now come in various forms and more commonly mix the written word with the iconic and visual (Cope and Kalantzis 2000; Barton et al. 2000, Kress 2003). Literacy is as much governed by the logic of the screen as the page and reading and writing are framed within a broader notion of multimodal design and meaning-making. Digital and silicon literacies have therefore become more significant in the landscape of communication. Similarly, Lemke's work (1998) on the post-compulsory curriculum in science suggests that students must learn to co-ordinate and use multiple literacies in an integrated manner across different genres and across diverse semiotic modes (verbal, visual and written), even when not using digital technology.

We therefore see a far more complex semiotic landscape than that framed in discourses of functional literacy, one which points to multiplicity but is also caught up in enactments of education to exert certain standards, those literacy practices to be valued. Here existing standards built upon assumptions of reading and writing text primarily using paper and pen are put into question. Literacy practices are multiple and different in different domains of our lives (Barton and Hamilton 1998). Literacy practices co-emerge with contexts of meaningful use, and communicating with multimodal semiotic resources will have consequences for participants' identities (see also Ivanič 1998, 2004b, 2006, Gee 1999, 2003).

The focus of the LfLFE project was on this multiple and multiplying semiotic landscape, on differences in literacy practices from one domain to another, and on the values, knowledge, 
expectations and subject positions which are inscribed in them. These different practices are shaped by hierarchies of value and taste of both those engaged in them and of others. Not only is there a hierarchy between different literacy practices, for example, reading a novel and texting someone, but there is also a valuing of what constitutes literacy and what does not, where, for instance, texting is not necessarily counted as literacy because it does not entail the standardized spelling and grammar associated with educational practices (Crystal 2008). Who has power to name these positions within hierarchies and which are powerful in the realization of literacy and learning as practices, and in enacting what is to count as literacy in specific domains become important questions.

As some literacy practices are more dominant or influential, everyday practices are often devalued within educational contexts. This is despite the many pedagogical attempts to relate learning across domains, e.g. simulations, the recognition of prior learning and work-based learning. It was this that led us initially to conceive our task as to identify border literacy practices and support the border crossing of these practices from the informal (everyday) to the formal (college). This was in order that they could become resources for learning and authorized in the teaching, learning and assessment associated with attainment in particular subject areas within colleges. We soon found the data indicating a far more complex relationship among literacy practices across domains.

Contextually sensitive theorizations of literacy have led us therefore, like others (e.g. TuomiGrohn and Engestrom 2003a, Eraut 2004), to question a simple view that skills can be transferred unproblematically from context to context. It is argued that to cross borders between contexts entails a disembedding and recontextualization of skills, including literacy, which is not fully captured in autonomous models of literacy as a set of functional skills. It 
also involves a recognition of the polycontexuality of practices, the fact that people belong to a number of networks within which the same artifacts might be used differently, or used the same but given differing meanings (Guile and Young 2003). Thus, writing an email in a class and one at home may look like the same activity, a similar literacy event. However, as a literacy practice, its meaning may vary significantly due to the different configurations of the aspects of literacy, for example, purpose, in the first for an assessment, in the second for maintaining friendship networks.

\section{Reconceptualizing 'the context' for literacy and for learning}

Trying to identify border literacy practices led us therefore to question assumptions about context. Context can be read at a variety of levels e.g. life, college, subject, course, teaching session and cannot be taken for granted as having bounded horizons. One common view of context treats it as a bounded container into which something else is placed, in, our case, literacy practices.

In all commonsense uses of the term, context refers to an empty slot, a container, into which other things are placed. It is the 'con' that contains the 'text', the bowl that contains the soup. As such, it shapes the contours of its contents: it has its effects only at the borders of the phenomenon under analysis... A static sense of context delivers a stable world. (McDermott 1996, 282)

In this view, literacy practices are bounded by contexts and often explained by them as well. They are a container within which literacy takes place. When context is theorized in this way, literacy arises from the specific context or situation in which it is manifested. This is one reading of the notion that literacy practices are situated, i.e. they are context bound. Lave 
(1996) argues that this concept of a context as a container paradoxically fuels attempts to promote practices in educational institutions that value precisely abstracted and generalized literacy practices, such as essay writing. Because the context provides an excluding boundary, literacy practices are separated from that which goes on outside educational institutions and abstraction and generalized practices become valued. Outside educational institutions the value of essay writing might be put under question. This is an extension of the argument that has been made in relation to knowledge that education develops decontextualized forms of knowledge (Chaiklin and Lave 1996). Through separation or what in actor-network theory (Latour 1993) is termed 'purification', bounded contexts are both assumed and enacted. As a result, certain literacy practices become naturalized as literacy per se and taken for granted as the standards against which all literacy practices can and should be measured.

Theorists interested in the spatial dimensions of learning have reflected on the benefits and difficulties associated with describing a learning 'landscape', and social semioticians refer to 'the multimodal communicative landscape' (Kress 2003, Ivanič 2006), all implying the importance of context. Such metaphors can, however, still construct contexts as a backcloth against, or container within which practices take place, whereas we position them as coemergent with semiosis and identification. Literacy practices, identifications and learnings are all 'objects-in-process' or 'processes-in-the-realization-of-object'. The bifurcation of verbs and nouns is elided here: 'context' entails 'contextualization'; 'identity' entails ‘identification' and 'space' entails ‘spatialization'. We follow Van Oers (1998) and Nespor (2003) therefore in challenging the somewhat static notion of context by drawing on alternative notions of 'contextualizing' and 'network contextualizers' respectively, which focus on contextualization as a set of enactments rather than on context as a pre-existing fixed 
space or entity. It is for this reason also that we have followed Barton and Hamilton (1998) in referring to literacy practices in different domains rather than contexts.

\section{Beyond borders: Purification, naturalization and translation}

However, we have found that even these more process-oriented notions can all too easily be collapsed back into a logic of context as bounded container. It is partly for this reason that we have adopted more relational understandings which focus on the people and artifacts that are networked through iterative practices of 'purification', 'naturalization', and 'translation' (Latour 1993, Bowker and Star 1999) as the basis upon which to understand how certain practices are included and excluded as standards of literacy to be practiced and demonstrated. Drawing selectively and creatively upon ANT provides us with an alternative through which to describe the alignments of animate and inanimate actants in the naturalization of certain literacy practices as effects of purification, and the translations which contribute to and resist this effect. Here acting is not restricted to the intentional practices of humans, but is equally an aspect of the inanimate world. Treated equally - symmetrically - both the animate and the inanimate are actants within a network that makes things happen (Latour 1999). Thus, for instance, humans cannot write without certain tools and technologies that enable representation. Let us now try and unpack what this means for literacy in educational practice.

Curriculum and pedagogy are at the heart of educational practices. Each enacts a form of selection and selection entails standards. However inclusive the practices are intended to be, education is the enactment of standards. In ANT terms therefore, learning in educational domains entails purification and naturalization through the standards practiced. 'Purification' refers to the way in which the identity of the educated subject is assembled upon the basis of the denial of the play of multiplicity and difference and the valuing of specific practices over 
others, for example, essay writing over texting, literature over popular magazines, the book over television. Standards are mobilized to select and purify in terms of the what and how of literacy and the people to be included. The term purification then refers to the ways in which learners and learning are bounded, classified and set apart, contained, based upon their capacity to communicate is specific ways. Purification entails the exclusion of that which is not valued. In terms of literacy practices, purification is a process of excluding those practices which are not considered standard, for example, literacy practices which do not employ 'proper' grammar, spelling, genre, etc.

The setting of standards requires value judgments and enactments of what is to be included and excluded - purification - and once this work is achieved, its common sense existence is naturalized. 'Naturalization means stripping away the contingencies of an object's creation and its situated nature. A naturalized object has lost its anthropological strangeness' (Bowker and Star 1999, 299). The concept of 'naturalization' refers to the outcome of purification insofar as the object becomes taken for granted rather than viewed as the result of contingent enactments. This is how literacy becomes seen as a unified thing rather than as a multiple range of enactments. The work of standards and standardization effectively becomes lost as certain forms of reading and writing are simply accepted as norms.

However, practices of naturalization do not need to be based upon purification alone, but can be framed within a logic of difference, which embraces practices of 'translation'. Translation 'creates mixtures between entirely new types of beings, hybrids of nature and culture' (Latour 1993: 10). Thus, the development of different forms of communication, for example, through the use of icons, becomes something not to be decried as a falling away from standards of literacy, but as a different possibility for communication. Such a framing involves describing 
practices in terms of creativity and desire as much as understanding and technique, something which is not necessarily comfortable to educators who are largely assembled within a culture of rationality.

Our argument then is not that translation is simply an alternative to purification. To argue this would be to work within an either-or logic. Our argument by contrast seeks to work with the logic of both-and. We can see aspects of both purification and translation in educational practices, since working to standards is never entirely pure and mixing is not infinite. Thus, in our data, we found examples in classrooms of both writing essays, but also the use of magazines to explore certain issues. The dominant discourse of education may focus on the need to purify, but the day-to-day practices of colleges demonstrate that multiplicity is already engaged with to a greater or lesser extent. Purification entails cutting away from networks, but this is never fully possible.

What results from this is a focus on naturalizing as a process which orders and reorders literacy practices, rather than context as a bounded, pre-existing container for them. Naturalizing is itself an outcome of a set of practices - practices of purification and translation - through which a context emerges, one form of which might be as a bounded container. Here different networking practices make different contexts, meaning that the same objects may be part of different naturalizations, by being networked differently. For instance, a computer can be networked into many different sets of practices, for example, gaming, messaging, writing assignments, searching for information. Literacies for learning therefore rely on the naturalization practices in play of all actors and the power and hierarchies of value that make certain naturalizations more likely than others. 
The relationships between literacy practices, learning and the curriculum are dynamic and complex, their characteristics are not symmetrical nor constant across domains, not least because different forms of work enact different (forms of) contexts. Different naturalizations may bring forth different interactions between literacy use and the learning of different knowledges and skills. The LfLFE project sought to bring these different interactions to the fore, to challenge the basis on which purification and naturalization are achieved, and to move forward the conceptual apparatus for describing such processes.

What then have we learnt from the above for our conceptualizing of literacy for learning? Our initial focus was on the movement of literacy practices from one context to another - from the everyday to the college - thereby assuming their situatedness within those separate and bounded contexts. We did not initially pay attention to the work that was involved in situating those literacies within those contexts and the establishing of those situations as contexts. In other words, their situatedness was taken for granted as a background context, rather than being identified as an effect of specific work to naturalize them, that is, to make them appear to be 'common sense' so that they would be taken for granted. We were thus entangled in a metaphorical complex that is often at the core of educational discourses of learning, which brings to the fore notions of journeying, travel and mobility from one bounded context (e.g. a football club) to another (e.g. a classroom). Here we were located theoretically within existing literature on situated learning (Lave and Wenger 1991), boundary crossing (Wenger 1998) and polycontextuality (Tuomi-Gröhn and Engeström 2003b). However, this set of assumptions was challenged in the course of the project. We have come to question these metaphors of movement, border crossing and flow as insufficient in themselves to develop an adequate language of description for what was going on in the data. 


\section{Reconceptualizing 'transfer': Scrumpling and folding}

Are the translations of literacy practices from one domain to another for the purposes of learning something possible or desirable? Does the context co-emerge with the literacy practices enacted? In what ways do purifying practices work against such possibilities? Does naturalization arise from the transfer of practices and objects from one context to another, from new learning, and/or from the networking of different animate and inanimate actants to enable an opening of certain possibilities based on the closing of others?

The final component in our theoretical framing, what is more conventionally known as conceptualizing 'transfer', is a conjecturing of the relationships among literacy practices across different domains of social life. We prefer the term 'domain' to the term 'contexts', because it disallows the tendency to retreat to notions of context as container and of life as a twodimensional landscape, and insists on a conceptualization of the ways in which aspects of social life are juxtaposed in a more three-dimensional way - as more scrumpled, more volatile, yet potentially more solid, if only 'stabilized for now'. Our alternative conceptualization of these relationships is served better by geological metaphors of social life operating in simultaneous and often messy and compacted conglomerations of practice, rather than by geographical metaphors of social life as a two-dimensional map in which contexts are defined by regions and borders. The concept of 'scrumpling' refers to the possibilities for experimentation in pedagogy and curriculum if we adopt an alternative topography, borrowed from Deleuze and Guattari (see Doel 1996), to that of purification and naturalization. This topography both assumes and promotes difference and multiplicity.

A question then arises whether we seek to relate different literacy practices across domains within the current regime of purification or to change the regime. The former is framed within 
the logic of an existing semiotic landscape of situated contexts, while the latter arises in and from a more scrumpled geography in which the very possibility for purification per se is thrown into question. Such a conceptualization can entertain the prospect of a new regime emerging which contains within it the desire for difference negotiated as a tension within the pedagogic (en)counter. Here there is the constant play of purification and translation dependent upon the networks of actants practiced, which may vary significantly within the same physical location.

We use the spatial metaphor of folding through which to conceptualize the work of this project, where pedagogic practice entails enactments to naturalize the hybrid, in which naturalization is framed within a logic of translation and purification, whereby both essays and magazines have pedagogic possibilities and value. There is thus a constant tension and struggle over that which is inside and outside in pedagogic practices of difference. This implies that any observation about learning something needs to be accompanied by observations regarding what has been naturalized and under what regime, the semiotic practices associated with the learning, and consequences for the identity of participants. The communicative as well as the cognitive and practical has to be part of the explicit pedagogical (en)counter.

This is not supportable by concepts of activity systems, nor communities of practice, each of which can be read as a series of containers, between which people, objects, practices, meanings move. Here we point to the significance of thinking in terms of folding in contrast with notions of crossing borders or boundaries from one context to another. Folding entails work and can take multiple different forms signifying the play of purity and multiplicity in naturalization. Folding can entail many different points of (dis)connection. There is also the 
possibility of unfolding, which means that literacy practices are insecure, the work to keep them naturalized needs to be sustained if those practices are to continue. Folding is three dimensional where the boundaries are negotiable and not simply assumed to be at the edge of a context as container; boundaries and connections are made through the practices of folding. Folding is therefore conceptually more resonant with the networking ideas now informing this study than notions of transfer.

We have found that simple dichotomies or binaries, therefore, such as informal/formal, vernacular/formal, contextualized/decontextualized, participation/acquisition and purification/translation prove inadequate for investigating literacies for learning. This points to the limitations of a border crossing metaphor in conceptualizing notions of transfer. It also points to the necessity for a more sophisticated understanding of contextualizing (for orienting discussion, see Edwards and Miller 2007, Edwards and Fowler 2007, Edwards et al. 2009). The LfLFE project has focused on the extent and nature of literacy practices as factors that distinguish one contextualizing for learning from another. Here contextualizing can affect the work of purification by separating out and bounding only certain practices as worthwhile the classroom context is an effect of practices which exclude many forms of literacy. We have been interested in those occasions, existing or potential, when literacy is or might be practiced in the service of learning something, always recognizing the interdependence of this relationship with naturalizing and identification.

Thus the metaphors of border literacies and of mobilizing literacy resources from one domain to another need to be put aside in the framing of our data, as sustained by a set of assumptions that we no longer see as theoretically or metaphorically adequate to the pedagogical challenges we have addressed. We see these processes not as simple border-crossings, but as 
complex reorientations or changes in foldings and in naturalization processes, which entail effort, awareness-raising, creativity and identity work on the part of all concerned. These foldings enact different networks of people and objects, which is the central insight of actornetwork theory.

What role then might we identify for 'boundary objects' in this framing? Given that boundaries and borders both connect and divide, what might be the nature of such objects? In trying to frame a better understanding of the networking of literacy practices in terms of the folding of three-dimensional space, we cannot totally disregard the existence of borders that bound - physical, cognitive, affective, imaginary. We cannot wish purification away. In folding, which may bring the near or far into relationship depending on the nature of the folds, boundary objects may help to make that relating possible. They help to do the work of naturalizing literacy practices.

\section{The role of boundary objects}

The notion of boundary objects has developed in ANT-related work (Star 1989), but has also been taken up by Wenger (1998) in his conceptualization of communities of practice. It is also to be found in activity theory. For Wenger (1998: 107) boundary objects work at the edges of communities of practice mediating their external relationships; 'they enable coordination, but they can do so without actually creating a bridge between the perspectives and the meanings of various communities'. However, we would caution against a simple uptake of Wenger's view of boundary object, precisely because these sit at the edge of communities, when, as we have indicated, in ANT, these objects can sit anywhere within a network. The latter is more in keeping with the theoretical position adopted here, as the former still seems to indicate the notion of context as container rather than the more relational understanding we favour. 
In ANT, boundary objects are

plastic enough to adapt to local needs and the constraints of the several parties employing them, yet robust enough to maintain a common identity across sites. [. . .] They have different meanings in different social worlds but their structure is common enough to more than one world to make them recognizable, a means of translation. The creation and maintenance of boundary objects is a key process in developing and maintaining coherence across intersecting social worlds. (Star and Griesemer 1989: 393)

"Like the blackboard, a boundary object "sits in the middle" of a group of actors with divergent viewpoints' (Star 1989: 46). Such objects are not merely material; they can be 'stuff and things, tools, artifacts and techniques, and ideas, stories and memories' (Bowker and Star 1999: 298). They are objects which are not contained nor containable by context, but can be folded between differing domains, dependent on the various affordances at play and the work entailed in naturalizing them differently within networks.

Objects exist, with respect to a community, along a trajectory of naturalization. This trajectory has elements of both ambiguity and duration. It is not predetermined whether an object will become naturalized, or how long it will remain so, rather practice-activity is required to make it so and keep it so. (Bowker and Star 1999: 299)

As we have indicated, this trajectory of naturalization entails a 'forgetting' of the conditions which gave rise to the object in the first place. Boundary objects do not sit between the borders of different contexts, at the edge, but express a relationship between domains brought together through the enactments of folding, purification and translation. These can be based upon pedagogic performances which seek to make certain connections rather than deny them, 
or simply because they are the tokens through which people relate their practices between one domain and another (Gaskell and Hepburn 1998). They do not pre-exist practices, but rely on those practices to make them into boundary objects.

As boundary objects are understood as not merely material objects, but can be 'stuff and things', there is the possibility for quite refined understandings of changes in practice that can alter the possibilities for folding and naturalization. This suggested the need to explore micropractices, in our case the micro-practices of literacy. By micro-practices, we are referring to the full range of actors that enable specific enactments of reading and writing in specific domains. This entails engaging with issues such as space and time, and forms of working as well as specific questions about reading and writing. The latter are only enacted and enactable through the networking of a range of what we have come to call micro-practices.

The tutors in the colleges contributing to the LfLFE project worked to fine-tune the reading and writing on their courses in order to achieve maximum resonance with students' literacy practices from other domains. They found, however, that what could be folded from one domain to another were not fully-formed literacy practices, and not texts or technologies on their own, but aspects of the practices: micro-practices such as collaboration, or non-linear processing. The implication of this for literacy studies is that while 'macro-literacy practices' are situated and cannot be mobilized wholesale to other contexts, 'micro-literacy practices' can be sufficiently naturalized to more than one domain, to the extent that they can be folded between them. However, it also leads us to probe what exactly we mean by micro-literacy practices.

\section{Micro literacy practices}


The LfLFE project found that 'whole' literacy practices, in the sense of social practices which involve the use of written language, such as applying for Child Benefit, or reading horoscopes, cannot be folded wholesale into educational settings, because the domain changes the practice. Nor, at the other extreme, is the current notion of transferable skills satisfactory, since reading and writing are shaped by the networks of which they are part. Nor is it simply a question of bringing apparently 'authentic' texts from other domains into educational settings, because they are no longer authentic to their new domain (see also Breen 1985 for this argument). In order to pursue our original intention of identifying ways in which students' everyday practices might be naturalized for their learning on college courses, we needed a way of theorizing literacy practices which allowed us to talk about their fine detail. In other words, it became necessary to look at the ways in which macro-literacy practices were themselves assembled by a network of micro-practices. Here a literacy practice is not a single unified object, but itself a network effect of actions and objects.

The idea that a literacy practice can be analyzed using a set of categories is implicit in literacy studies and has been discussed explicitly by, for example, Hamilton (2000) in her article distinguishing visible and non-visible elements of literacy events. This was a useful startingpoint, but we found it necessary to extend and reconfigure this list for our own purposes. We have also positioned these categories as actants within networks to capture the fact that they only emerge as micro-practices insofar as they are taken up; they are not inherent constituents of such practices. We have presented these in different ways for different purposes (see, for example, Pardoe and Ivanič 2007, Ivanič et al. 2007, 2009, Ivanič and Satchwell 2007, Satchwell and Ivanič forthcoming). Figure 1 provides an overview of aspects of a literacy practice which proved salient on the LfLFE project. It provides an analytical tool for 
interrogating data, for talking explicitly about micro-literacy practices and for considering pedagogic practices.

\begin{tabular}{|c|c|c|c|}
\hline & $\stackrel{\tilde{\Xi}}{\tilde{\Sigma}}$ & $\hat{\vec{े}}$ & 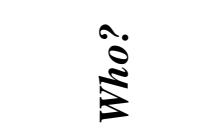 \\
\hline & \multicolumn{3}{|c|}{ Aspects of a literacy practice } \\
\hline & content & purpose(s) & audience(s) \\
\hline $\begin{array}{l}\text { Under } \\
\text { what } \\
\text { conditions? }\end{array}$ & $\begin{array}{c}\text { language(s), } \\
\text { genres, styles } \\
\text { and design }\end{array}$ & $\begin{array}{l}\text { flexibility } \\
\text { and } \\
\text { constraints }\end{array}$ & $\begin{array}{c}\text { roles, } \\
\text { identities } \\
\text { and values }\end{array}$ \\
\hline How? & $\begin{array}{l}\text { modes and } \\
\text { technologies }\end{array}$ & $\begin{array}{c}\text { actions and } \\
\text { processes }\end{array}$ & participation \\
\hline
\end{tabular}

Figure1: Aspects of a literacy practice

Some of the aspects in the framework are common to all practices, and might be used to describe an activity which does not have a significant communicative dimension to it, for example, playing football. Purpose(s), identities, roles and values, participation, activities and processes, and flexibility and constraints are aspects of any practice. Other aspects in the framework are specific to communicative practices and literacy practices. The aspects on the left of the diagram: content, language(s), genres, styles and design, modes and technologies, are specific to literacy practices, and audience is a specific aspect of the 'Who' in literacy practices. Even the more general aspects in the framework have particular characteristics in a communicative practice. For example, in a communicative practice, the 'actions and 
processes' include both physical and mental ways of engaging with or composing text actions which would not be significant in some social practices.

The nine aspects each instigate a line of inquiry about a literacy practice, but they are not hermetically sealed from one another. For example, a discussion of conventions of style and design will overlap with the identification of modes and technologies. Each of the aspects in the middle and bottom rows of the framework combines responses to two questions. For example, 'Flexibility and constraints' is concerned with 'Why' the practice is the way it is, and 'Under what conditions' the other aspects of the practice are operating. Each aspect can be further subdivided to achieve a greater degree of delicacy. For example, 'Actions and processes' can be further analysed into categories of time, space, movement and so on. The questions provide the 'way in', and the nine aspects in the framework work in concert with the questions to provide a rich description of a literacy event or practice, or to provide a basis for comparison among practices.

Each of the aspects in the framework can be understood on least two levels. They can be seen firstly as factors which are amenable to observation and the collection of concrete evidence from specific literacy events. For example, the 'Participation' aspect invites attention to details of who is involved and how they are interacting with one another. However, we can also move beyond the immediate, descriptive detail of literacy events to engage in deeper probing through participant accounts, interpretation, processes of abstraction and making connections between the local and the institutional domains in which the literacy events are located. This constitutes a move from the analysis of observable events to the analysis of literacy practices as a network effect. For example, at this more abstract level, the 'Participation' aspect invites attention to participants' understandings of their rights and 
responsibilities as participants in the practice, to 'rules of engagement', and habitual structures of participation in the practice.

Each of these micro-literacy practices can be configured in many ways. In the LfLFE project, we identified a number of characteristics of the literacy practices students choose to engage in. These practices tended to be:

* purposeful to the student

* oriented to a clear audience

* generative, i.e. involving meaning-making, creativity and getting things done

* shared, i.e. interactive, participatory and collaborative

* in tune with students' values and identities

* non-linear, i.e. with varied reading paths

* specific to times and places

* multi-modal, i.e. combining symbols, pictures, colour, music

* multi-media, i.e. combining paper and electronic media

* agentic, i.e. with the students having control

* self-determined in terms of activity, time and place

* varied; not repetitive

learned through participation

Each of the micro-practices can be configured in many ways, and change in any one of them changes the nature of the practice. To put it another way, each actant has a potentially infinite number of 'frequency settings' according to the particular macro-practice within which they are assembled. So, for example, in many of the literacy practices in which the students in the LfLFE project engaged in when not doing college work, the reading and writing processes were non-linear: moving from one part of a text to another and reading, or writing, at variable 
speeds according to the part of the text. In the reading and writing they were expected to do on their courses, however, there was an assumption that the text would be read or written sequentially. In turn, the configurations can be folded in infinite ways, and the combinations, if repeated often enough for them to become naturalized, might become 'stabilized for now', durable, as a macro-literacy practice. The possibilities suggest not a tidy landscape of literacy practices but a scrumpled geography in which each practice is a conglomerate subsumed but never entirely within a regime of purification which is working to exclude otherness, difference and multiplicity.

Not all actants of literacy practices have the plasticity to enable successful folding and naturalization and to become boundary objects. In our project this is in part because the translation of bringing the non-college into college learning could not always be naturalized within the existing regime and the regime itself was not subject to amendment. Some micropractices were capable of more resonance than others in the assembling of a network and some networking disrupted the existing enactment of purification. To take the magazines which students read outside college as an example, they were naturalized too much to the students' 'out-of-college' practices to be folded in for learning on their courses. The domains and purposes of the classroom were too different, too purified, and changed the practice of reading the magazines to such an extent that it was no longer engaging for the students. The ostensible resonance and vibrancy of using authentic texts in the classroom was lost in the different uptake, as certain of the micro-practices were no longer in play. Thus we found that not all aspects of practices could emerge as boundary objects within particular situations. For the LfLFE project, it also became apparent that some students were more inclined to work to maintain the boundaries between non-college life and college than to attempt to achieve any folding between them. They had neither the power to do this folding and naturalization work 
nor any investment in the creation of such boundary objects and were sometimes resistant to the claims being made upon their out of college identities and interests; there was too much distance for them to want their practices to be translated into the curriculum.

\section{The scrumpled geography of literacies for learning}

Literacy and learning can be seen as distributed through the range of networks within which a person is interconnected. These networks 'expand, contract and shift configuration over time, and even the most stable and predictable of them are constantly being reappropriated and redefined by the nature of the flows that animate them...' (Nespor 1994: 12). Literacies and the power exercised in and around them therefore can be seen as actor-networks, ordered in time and space. This approach then, rather than assuming a movement of literacy from one context to another, examines the work that goes into mobilizing and stabilizing certain situations as contexts through the attempted exclusion of multiplicity. Colleges are complex and contested organizational forms, within which there may be many tensions between the different pedagogical practices at play. The consequence is that, despite the multiplicity of literacy practices which are enacted outside educational domains, only certain forms are stabilized in establishing an educational and educated context.

The alternative topography of literacies for learning we now seek to develop entails engaging with the multiplicity and difference we have found in learning in the varying scrumpled domains of people's lives, and a recognition that the binary either-or logic and purification will not be sufficient for pedagogic practices. Literacy practices are temporary conglomerations, assembled multiples - networks - in themselves. While the current discursively strong regime of purification and naturalization is built upon the adoption of standards and the exclusion of otherness, there are possibilities for an alternative regime to be 
developed which creatively seeks the multiple translation and (un)folding of the micropractices of literacy into different domains. This entails a different regime of purification which embraces translation and otherness and naturalizes multiplicity. This is messy, emergent and non-linear and cannot be mandated in advance. Rather than seeking to flatten the landscape to expand the horizon, it entails scrumpling the landscape to explore different possibilities for conglomerations within and between domains. It entails assembling networks rather than journeying. This can never be entirely an open process as not all micro-practices stick, but this alternative regime at least provides the possibility for an education which is not based upon a reified standard of literacy to be achieved, but seeks to engage with the work that can be done through the multiplication and naturalization of literacy practices as actually practiced in the world.

In examining literacies for learning, therefore, the scrumpled geography is a landscape of both purification and translation. Such a landscape is never entirely dormant, not least because of the multiplying possibilities for literacy that are emerging from increasing foldings, from the diverse effects of the ensuing networks, and from the play of multiple enactments of purification and translation.

\section{Acknowledgements}

1. This article arises from work done within the Literacies for Learning in Further Education research project, funded by the ESRC's Teaching and Learning Research Programme (grant number RES-139-25-0117). Our thanks to all the members of the research and those who have participated in this work. It is also based upon work funded by the ESRC's Teaching and Learning Research Programme in a thematic seminar series, Contexts, Communities, Networks: Mobilizing Learners Resources and 
Identities Across Domains (grant number RES-139-25-0174). Our thanks to all who contributed to the seminar series.

2. Our thanks also to the two anonymous reviewers of this article who gave engaged and constructive feedback, which we have attempted to fold into the final text.

\section{Bibliography}

Barton, D. (2007) Literacy: An introduction to the ecology of written language (2nd ed). Oxford: Blackwell.

Barton, D. and Hamilton, M. (1998) Local literacies: Reading and writing in one community. London: Routledge.

Barton, D., Hamilton, M. and Ivanič, R. (Eds.) (2000) Situated literacies: Reading and writing in context, London: Routledge.

Bowker, G. and Star, S. (1999) Sorting things out: Classification and its consequences. Cambridge, Mass.: MIT Press.

Breen, M. P. (1985) Authenticity in the language classroom. Applied Linguistics 6: 60-70.

Chaiklin, S. and Lave, J. (Eds.) (1996) Understanding practice. Cambridge: Cambridge University Press.

Cope, B. and Kalantzis, M. (Eds.) (2000) Multiliteracies, London: Routledge.

Crystal, D (2008) txtng: the gr8 db8, Oxford: Oxford University Press.

Czarniawska, B. and Hernes, T. (Eds.) (2005) Actor-network theory and organizing. Malmo: Liber and Copenhagen Business School Press.

Doel, M. (1996) A hundred thousand lines of flight: a machinic introduction to the nomad thought and scrumpled geography of Gilles Deleuze and Felix Guattari. Environment and Planning D: Space and Society 14: 421-439. 
Edwards, R. and Fowler, Z. (2007) Unsettling boundaries in making a space for research. British Educational Research Journal 33(1): 107-23.

Edwards, R. and Miller, K. (2007) Putting the context into learning. Pedagogy, Culture and Society 15(3): 263-74.

Edwards, R., Biesta, G. and Thrope, M. (eds) (2009) Rethinking Learning and Teaching in Context. London: Routledge.

Eraut, M. (2004) Informal learning in the workplace. Studies in Continuing Education 26(2): $247-74$

Gaskell, J. and Hepburn, G. (1998) The course as token: A construction of/by networks. Research in Science Education 28(1)

Gee, J. P. (1999) An introduction to discourse analysis: Theory and method. New York: Routledge.

Gee, J. P. (2003) What video games have to teach us about learning and literacy. New York: Palgrave: Macmillan.

Guile, D. and Young, M. (2003) Transfer and transition in vocational education: some theoretical considerations. In T. Tuomi-Grohn and Y. Engestrom (Eds.), Between work and school: New perspectives on transfer and boundary-crossing. London: Pergamon.

Hamilton, M. (2000) 'Expanding the New Literacy Studies: using photographs to explore literacy as a social practice', in D. Barton, M. Hamilton and R. Ivanič (eds) Situated Literacies: reading and writing in context, London: Routledge.

Ivanič, R. (1998) Writing and identity: The discoursal construction of identity in academic writing. Amsterdam: John Benjamins.

Ivanič, R. (2004a) Discourses of writing and learning to write. Language and Education 18(3): $220-245$. 
Ivanič, R. (2004b) Intertextual practices in the construction of multi-modal texts in inquirybased learning. In N. Shuart-Faris and D. Bloome (Eds.) Intertextuality and literacy in clasrooms: Directions in educational research. Westport, CT.: Greenwood Publishing Group.

Ivanič, R. (2006) Language, learning and identification. In R. Kiely, P. Rea-Dickens, H. Woodfield and G. Clibbon (Eds.) Language, Culture and Identity in Applied Linguistics. Equinox.

Ivanič, R. and Satchwell, C. (2007) Boundary crossings: Networking and transforming literacies in research processes and college courses. To appear in the Special Issue of The Journal of Applied Linguistics on New Directions in Academic Literacies Research.

Ivanič, R., Edwards, R., Satchwell, C. and Smith, J. (2007) Possibilities for pedagogy in further education: harnessing the abundance of literacy. British Educational Research Journal 33(5): 703-21

Ivanič, R., Edwards, R., Barton, D., Martin-Jones, M., Fowler, Z., Hughes, B., Mannion, G., Miller, K., Satchwell, C. and Smith, J. (2009) Improving Learning in College: Rethinking literacies across the curriculum. London: Routledge.

Kress, G. (2001) "You've just got to learn how to see": Curriculum subjects, young people and schooled engagement with the world. Linguistics and Education 11(4): 401-15.

Kress, G. (2003) Literacy in the new media age. London: Routledge.

Latour, B. (1993) We have never been modern. London: Harvester: Wheatsheaf.

Latour, B. (1999) Pandora's hope. Cambridge, Mass.: Harvard University Press.

Latour, B. (2005) Reassembling the social: An introduction to actor-network theory, Oxford: Oxford University Press. 
Lave, J. (1996) The practice of learning. In S. Chaiklin and J. Lave (Eds) Understanding Practice: Perspectives on Activity and Context, Cambridge: Cambridge University Press.

Lave, J. and Wenger, E. (1991) Situated learning. Cambridge: Cambridge University Press. Lee, A. (1996) Gender, literacy, curriculum: Rewriting school geography. London: Taylor and Francis.

Lemke, J. (1998) Multiplying meaning: Visual and verbal semiotics in scientific text. In J.R. Martin and R. Veel (Eds.) Reading science. London: Routledge.

McDermott, R. (1996) The acquisition of a child by a learning disability. In S. Chaiklin and J. Lave (Eds.) Understanding Practice: Perspectives on Activity and Context. Cambridge: Cambridge University Press.

Nespor, J. (1994) Knowledge in motion. London: Falmer.

Nespor, J. (2003) Undergraduate curricula as networks and trajectories. In R. Edwards and R. Usher (Eds.) Space, Curriculum and Learning. Greenwich: IAP.

Pardoe, S. and Ivanič, R.(2007) Literacies for learning in further education: Making reading and writing practices across the curriculum more useful for learning. DVD and accompanying booklet. Lancaster: PublicSpace Ltd (www.publicspace.org.uk).

Satchwell, C. and Ivanič, R. (forthcoming) Reading and writing the self as a college student: Fluidity and ambivalence across contexts. In K. Ecclestone, G. Biesta and M. Hughes (Eds.) Lost in transition? Change and becoming through the lifecourse. London: RoutledgeFalmer.

Star, S. L. (1989) The structure of ill-structured solutions: boundary objects and heterogeneous distributed problem solving. In L. Gasser and M. Huhns (Eds.), Distributed Artificial Intelligence, Vol. II. London: Pitman. 
Star, S. L. and Greisemer, J. (1989) Institutional ecology, 'translations' and boundary objects: Amateurs and professionals in Berkeley's Museum of Vertebrate zoology, 1907-39. Social Studies of Science 19: 387-420.

Tuomi-Gröhn, T. and Engeström, Y. (Eds.) (2003a) Between work and school: New perspectives on transfer and boundary-crossing. London: Pergamon.

Tuomi-Gröhn, T. and Engeström Y. (2003b) Conceptualizing transfer: From standard notions to developmental notions. In T. Tuomi-Gröhn and Y. Engeström (Eds.), Between work and school: New perspectives on transfer and boundary-crossing. London: Pergamon.

Van Oers, B. (1998) From context to contextualizing. Learning and Instruction 8(6): 473-88.

Wenger, E. (1998) Communities of practice. Cambridge: Cambridge University Press.

Wyatt-Smith, C. and Cumming, J. (2003) Curriculum literacies: Expanding domains of assessment. Assesment in Education 10(1): 47-59. 